\title{
Starch and flour extraction and nutrient composition of tuber in seven cassava accessions
}

\author{
M. S. A. Fakir, M. Jannat, M.G. Mostafa and H. Seal ${ }^{1}$ \\ Department of Crop Botany, ${ }^{1}$ Department of Agricultural Chemistry, Bangladesh Agricultural University, Mymensingh- \\ 2202, Bangladesh, Email: fakirmsa@gmail.com
}

\begin{abstract}
Cassava (Manihot esculenta Crantz) roots (tubers) are used as staple food. Starch extracted from tubers is widely utilized as raw materials in industries. Dry matter (DM) content, starch and flour extraction and proximate composition were investigated in seven cassava accessions (Coc- $A_{1}, K h-A_{2}$, Cow- $A_{3}$, Sa- $A_{4}$, Me- $A_{5}$, Va- $A_{6}$ and Sy- $A_{8}$. in $2010-$ 2011. Leaf DM varied from $20.51 \%$ in $M e-A_{5}$ to $29.01 \%$ in Sy- $A_{8}$; that of stem from $27.24 \%$ in $V a-A_{6}$ to $32.10 \%$ (average of Sy-A $\mathrm{A}_{8}, \mathrm{Me}-\mathrm{A}_{5}$ and $\mathrm{Sa}-\mathrm{A}_{4}$ ); and that of tuber from $37.30 \%$ in $\mathrm{Kh}-\mathrm{A}_{2}$ to $45.26 \%$ in Sy-A $\mathrm{A}_{8}$ Starch was extracted by blending chopped tuber followed by decantation. Tubers were sliced, sun dried and milled into flour. Tuber starch content (fresh wt. basis) varied between $15.04 \%$ in Sy-A $A_{8}$ and $24.97 \%$ (average of Coc- $A_{1}$ and $M e-A_{5}$ ); that of peel from $4.54 \%$ in $\mathrm{Va}-\mathrm{A}_{6}$ to $5.85 \%$ in Coc- $\mathrm{A}_{1}$. Crude protein varied from $1.80 \%$ (average of Kh- $\mathrm{A}_{2}, \mathrm{Cow}-\mathrm{A}_{3}$ and $\mathrm{Sy}-\mathrm{A}_{8}$ ) to $4.53 \%$ in $\mathrm{Va}-\mathrm{A}_{6}$. Crude fiber content varied from $1.95 \%$ (average of Sa- $\mathrm{A}_{4}$ and $\mathrm{Coc}-\mathrm{A}_{1}$ ) to $4.27 \%$ in Cow- $A_{3}$. Cyanogens present in cassava plant escape as hydrogen cyanide $(\mathrm{HCN})$ during harvesting and processing. Variation for HCN existed and it was $140.95 \mathrm{mg} / \mathrm{kg}$ fresh tuber (average of Sy- $\mathrm{A}_{8}$ and Coc- $\mathrm{A}_{1}$ ) to $546.0 \mathrm{mg} / \mathrm{kg}$ fresh tuber in $\mathrm{Va}_{-} \mathrm{A}_{6}$. There was no detectable $\mathrm{HCN}$ in the extracted flour and starch. It may be concluded that genetic variation for $\mathrm{DM}$, starch, protein and $\mathrm{HCN}$ existed in seven cassava accessions, and Coc- $\mathrm{A}_{1}$ may be a better one due to its lower HCN, higher DM and starch content.
\end{abstract}

Keywords: Cassava roots, DM, HCN, Proximate composition

\section{Introduction}

Cassava (Manihot esculenta Crantz) is a perennial, subtropical, woody shrub, grown as annual and is valued for its underground starchy tubers (roots) (Grace, 1977; Purseglove, 1988; Islam et al., 2008). Cassava is the important source of energy as staple food for more than 500 millions people in Africa, Latin America and Asia (Hillocks, 2002). Tuber of cassava is also used as raw materials in the garment, bakery, food and Pharmaceutical industries (Bokanga et al., 1994; IITA, 2011; Fakir et al., 2012). Cassava root can be consumed raw as a snack or just after boiling like sweet potato. Cassava is a mesophyte and can be grown in fallow high land, hill slope, rice field dyke ('ail') and other unutilized high lands. It can be grown in poor soils and produce fairly good yield where other crops almost fails and provide food security (Siritunga et al., 2004). In Bangladesh, tribal people of Madhupur, Garo Hill, Natrokona and Chittagong Hill Tract region locally grows and eat cassava. There is a good potentiality of cultivating and introducing this crop to other areas in Bangladesh. Private entrepreneurs like 'Rahman and Chemical Co.' and 'Bharsha group' have also been producing cassava in the country through contact farmers in Comilla, Tangail and Chittagong Hill Tracts and utilising tuber for starch, glucose and glucose syrup production. There is no reliable statistics of areas and production in Bangladesh.

Dry matter (DM) determination in different genotypes of cassava is important since nutrition and energy calculation is based on magnitude and nature of DM content. Higher DM content naturally would provide greater yield once partition of the same is increased to the economic part. Boerboom (1978) and Islam et al. (2008) investigated dry weight of plant parts and observed that leaf, stem and tuber contained $30-60 \%$ DM. Cassava tuber contains about $70 \%$ moisture, $20-30 \%$ carbohydrate, $1.0-1.8 \%$ crude protein, $1.5-$ $3.5 \%$ crude fiber, $0.35-0.45 \%$ fat and $8-28 \mathrm{mg} \mathrm{HCN} / \mathrm{kg}$ of dry mass (Purseglove, 1988; Charles et al., 2005). Cassava plant parts are rich source of vitamins and minerals. Though tuber is the main product of cassava plant, its young branch and leaf is also edible both for human and animal (Fakir et al., 2010). Tuber is the main source of starch and minerals; leaf is the rich source of protein, vitamins and minerals. Cassava flour (10-30\%) in combination with wheat flour is used in bread industry to reduce pressure on wheat (Grace, 1977). Therefore, cassava flour along with mixture with wheat flour can be used to make nutritious food and food products. Its tuberous root contains (fresh weight basis) $30-40 \%$ dry matter (DM) and $25-30 \%$ starch. Nutritionally, cassava contains potassium, iron, calcium, vitamin A, folic acid, sodium, vitamin C, vitamin B-6, and protein (Montagnac et al., 2009). Nutritional quality especially protein can be added in composite flours (tapioca) in cassava-soya, cassava-peanut bread. The protein content of 'tapioca' is about $10 \%$ and the macaroni is nearly twice as nutritious as rice (Grace, 1977). Supplemental use of cassava flour and starch in combination with wheat flour may reduce pressure and thus would enhance food security in Bangladesh. 
Cassava flour is used for making bread and other products like Chips, jam, jelly and chutneys. Flour extraction from cassava tuber depends on reduction of moisture. Cassava drying aims at reducing its water content to less than 15\%. IITA (2005) cites four factors that influence drying of cassava (chips flour and starch). These are temperature, airflow, humidity and tumbling frequency. Starch from cassava tuber can be extracted in two simple, wet and sun dry, methods. In the wet method, fresh tubers are blended with adequate water and the filtrate is decanted to starch. The starch obtained is then dried in the sun and is ready for use. In wet method fresh tubers are certainly be used for flour production immediately after harvest, within $72 \mathrm{hrs}$, since fresh roots deteriorates quickly. In sun dry methods, fresh tubers are chopped into small pieces and are sun dried until desirable moisture content is achieved. The dried cubes are ground and milled into flour. The methods of flour extraction, therefore, also influence the degree of detoxification.

All parts of the cassava plants contain cyanogens that are hydrolyzed to hydrocyanic acid (HCN) that escapes into the air during harvesting and processing (Bokanga et al., 1994; Fakir et al., 2009). At harvest of cassava tubers, the amount of $\mathrm{HCN}$ acids varies from harmless to lethal. The lethal dose of $\mathrm{HCN}$ is $50 \mathrm{mg} / \mathrm{kg}$ fresh weight. Hydrolysis of glycoside by the enzyme can be accelerated by soaking the roots in water, by crushing or cutting them or by heating. $\mathrm{HCN}$ content of cassava roots could thus be reduced to a great extent by treating in such ways (Fakir et al., 2010). Although literatures on botany, physiology, nutrient content and $\mathrm{HCN}$ is available at home and abroad (Grace, 1977; Alves, 2002; Anonymous, 2004; Charles et al., 2005; Islam et al., 2008; Fakir et al., 2009, 2010, 2011), there is scanty information in Bangladesh on methods of flour and starch production and proximate composition of cassava tuber (Jannat, 2011; Fakir et al., 2012). So it was necessary (i) to estimate the dry matter content of plant parts; (ii) to investigate the methods of flour/starch extraction; and (iii) to determine the proximate composition of tuber of seven cassava accessions.

\section{Materials and Methods}

Plant establishment: The experiment was conducted at the field laboratory of the Department of Crop Botany, Bangladesh Agricultural University, Mymensingh during November, 2010 to October, 2011. Healthy and uniform size (about $15 \mathrm{~cm}$ with 5 to 6 nodes) 8 months old stem cuttings of seven cassava accessions (Coc- $A_{1} ;$ Kh- $A_{2} ;$ Cow- $A_{3} ;$ Sa- $A_{4} ;$ Me- $A_{5} ;$ Va- $A_{6}$ and Sy- $\left.A_{8}\right)$ were planted at $1 \mathrm{~m} \times 1 \mathrm{~m}$ spacing in $16 \mathrm{~m}^{2}$ plots. Stem cuttings were, collected from previous experiment, planted horizontally at 10 to $12 \mathrm{~cm}$ soil depth with one cutting per hole. The cuttings were treated for ten minutes with the fungicides 'Bavistin' @ $5 \mathrm{~g} / 10 \mathrm{~L}$ before planting. Seven treatments (seven accessions) were planted in a randomized complete block design (RCBD) with four replications.

Crop sampling and harvesting: After 10 months, four plants excluding border ones were randomly selected from each plot and harvested, cleaned and brought to the laboratory for further observations.

Peeling and dry matter content: After harvest, tubers were peeled and cut into small cubes $(2 \mathrm{~cm}$ long and $0.5 \mathrm{~cm}$ wide) for dry matter content. The dry matter contents of the different plant parts of cassava were determined by Benesi et al. (2004). The samples were sun dried following oven drying $\left(65^{\circ} \mathrm{C}\right.$ for 72 h) until constant weight and cooled in desiccators and weighed immediately. The drying and weighing steps were repeated until consecutive constant weights were achieved.

Starch extraction: Starch was extracted using the wet method described by Benesi et al. (2004). Fresh tubers were washed, peeled, chopped into approximately $1 \mathrm{~cm}$ cubes and then pulverized in a highspeed blender (Model KING, Osaka, Japan) for $5 \mathrm{~min}$. The pulp was suspended in ten times its volume of water, stirred for 5 minutes and filtered using double fold cotton cloth. The filtrate was allowed to stand for $2 \mathrm{~h}$ for the starch to settle and the top liquid was decanted and discarded. Water was added to the sediment and the mixture was stirred again for 5 minutes. Filtration was repeated as before and the starch from the filtrate was allowed to settle. After decanting the top liquid, the sediment (starch) was sun dried for $24 \mathrm{~h}$ and stored. The starch of peel was also extracted by the same procedure. Following is flow diagram of starch extraction. 


\section{Fakir et al.}

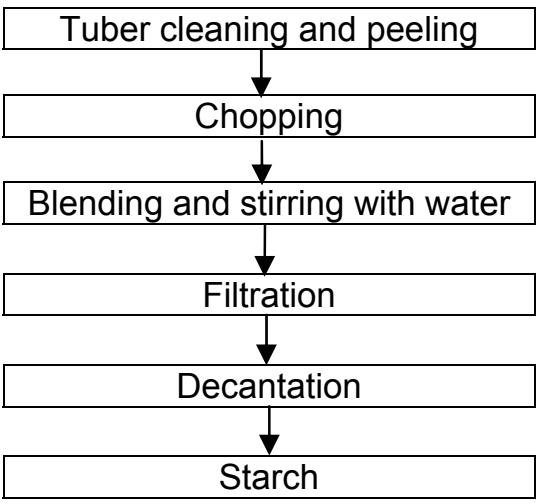

Dry matter (DM) content of starch, pulp and flour: DM content of starch was determined by the same procedure described earlier. The pulp (broken tissue plus fibers in moistened condition) after filtration was also sun dried and kept at $10-12 \%$ moisture for making flour. Flour was obtained after grinding dried pulp followed by sieving. Following is the flow diagram for flour production:

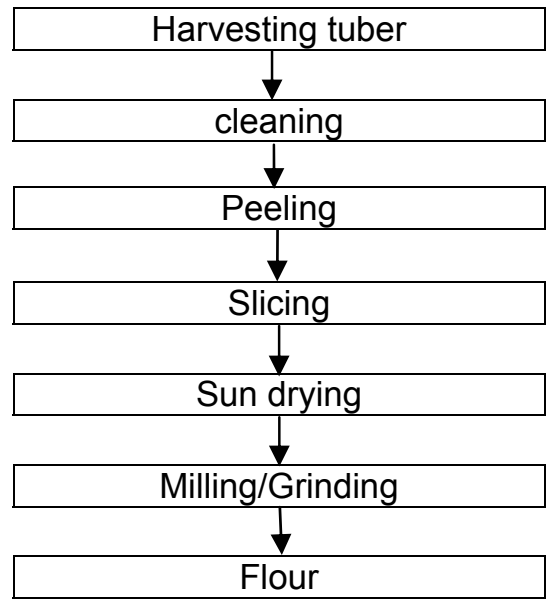

Tubers proximate composition: Crude protein (CP), crude fiber (CF), crude fat (EE), total carbohydrate (NFE) and ash were determined by AOAC (1990) and hydrogen cyanide (HCN) by Grace (1977).

Data collection and analysis: The data were compiled and analyzed to find out the statistical significance. The means for all the collected data were calculated and the mean differences were evaluated by Duncan's New Multiple Range Test (Gomez and Gomez, 1984).

\section{Results and Discussion}

\section{Dry matter (DM) content of plant parts}

Peel: The dry matter content of peel varied significantly $(P \leq 0.05)$ among the seven cassava accessions and it was greater in Coc- $\mathrm{A}_{1}, \mathrm{Kh}-\mathrm{A}_{2}$ and $\mathrm{Me}-\mathrm{A}_{5}$ (average of $24.58 \%$ ) than in the Sa- $\mathrm{A}_{4}$ and Cow- $\mathrm{A}_{3}$ (average of $21.72 \%)$, Va- $\mathrm{A}_{6}(18.99 \%)$ and $\mathrm{Sy}-\mathrm{A}_{8}(16.62 \%)$ (Table 1). Tuber: The tuber DM content varied significantly $(P \leq 0.05)$ from $37.30 \%$ in $K h-A_{2}$ to $45.26 \%$ in Sy- $A_{8}$ (Table 1). It was greater in Sy- $A_{8}$ $(45.26 \%)$ than $V a-A_{6}(43.79 \%)$, Cow $-A_{3}$, Coc- $A_{1}$, Sa-A $A_{4}$ and Me- $A_{5}$ (average of $41.08 \%$ ) and Rh- $A_{2}$. (37.30\%). On an average, tuber contained $41.53 \%$ DM i.e. $58.47 \%$ water in the current research. Stem: Stem DM content was greater in Sa- $\mathrm{A}_{4}, \mathrm{Sy}-\mathrm{A}_{8}$ and $\mathrm{Me}-\mathrm{A}_{5}$ (average of $32.10 \%$ ) than Coc- $\mathrm{A}_{1}$ $(29.97 \%)$ Cow- $\mathrm{A}_{3}(28.72 \%)$ and $\mathrm{Va}-\mathrm{A}_{6}(27.24 \%)$ (Table 1). Petiole: The DM content of petiole varied significantly $(P \leq 0.05)$ with greater magnitude in Cow- $A_{3}(31.91 \%)$ than in $V a-A_{6}(29.32 \%)$, Kh- $A_{2}$ (28.02\%), Me-A $\mathrm{A}_{5}$ and Coc- $\mathrm{A}_{1}$ (average of $26.42 \%$ ) and $\mathrm{Sa}_{-} \mathrm{A}_{4}(21.66 \%)$ (Table 1). Leaf lobe: Leaf lobe DM varied from $20.51 \%$ in Me- $A_{5}$ to $29.01 \%$ in Sy- $A_{8}$. The dry matter content of Leaf lobe was significantly greater in Sy- $A_{8}(29.01 \%)$ than Coc- $A_{1}$ and Cow- $A_{3}$ (average of $\left.26.97 \%\right), V a-A_{6}(24.36 \%)$, Kh- $\mathrm{A}_{2}$ and Sa- $\mathrm{A}_{4}$ (average of $22.50 \%$ ) and Me- $\mathrm{A}_{5}$ (20.51\%) (Table 1). 
Table 1. Dry matter (DM) content of plant parts of seven cassava accessions

\begin{tabular}{|l|c|c|c|c|c|}
\hline \multirow{2}{*}{ Accessions } & \multicolumn{5}{|c|}{ Dry Matter content (\%) } \\
\cline { 2 - 6 } & Peel & Tuber & Stem & Petiole & Leaf lobe \\
\hline Coc-A $_{1}$ & $24.79 \mathrm{a}$ & $41.38 \mathrm{c}$ & $29.97 \mathrm{~b}$ & $26.81 \mathrm{~d}$ & $27.28 \mathrm{~b}$ \\
\hline $\mathrm{Kh}_{2} \mathrm{~A}_{2}$ & $24.20 \mathrm{a}$ & $37.30 \mathrm{~d}$ & $29.10 \mathrm{bc}$ & $28.02 \mathrm{c}$ & $22.79 \mathrm{~d}$ \\
\hline Cow-A & $21.85 \mathrm{~b}$ & $40.88 \mathrm{c}$ & $28.72 \mathrm{c}$ & $31.91 \mathrm{a}$ & $26.67 \mathrm{~b}$ \\
\hline Sa- $\mathrm{A}_{4}$ & $21.59 \mathrm{~b}$ & $40.58 \mathrm{c}$ & $32.64 \mathrm{a}$ & $21.66 \mathrm{e}$ & $22.22 \mathrm{~d}$ \\
\hline Me-A & $24.75 \mathrm{a}$ & $41.49 \mathrm{c}$ & $31.80 \mathrm{a}$ & $26.04 \mathrm{~d}$ & $20.51 \mathrm{e}$ \\
\hline Va- $\mathrm{A}_{6}$ & $18.99 \mathrm{c}$ & $43.79 \mathrm{~b}$ & $27.24 \mathrm{~d}$ & $29.32 \mathrm{~b}$ & $24.36 \mathrm{c}$ \\
\hline Sy-A & $16.62 \mathrm{~d}$ & $45.26 \mathrm{a}$ & $31.88 \mathrm{a}$ & $29.12 \mathrm{bc}$ & $29.01 \mathrm{a}$ \\
\hline Mean & 21.83 & 41.53 & 30.19 & 27.55 & 24.69 \\
\hline
\end{tabular}

In a column, numbers followed by different letters differ significantly at $\mathrm{P} \leq 0.05$ by DMRT

Genetic variations for DM content of plant parts existed in the current research. Howeler and Cadavid (1983), Boerboom (1978) and Islam et al. (2008) also noted genetic variation for DM in different cassava accessions. Mean DM content was greater in tuber (41.53\%) than stem $(30.19 \%)$, petiole $(27.55 \%)$, leaf lobe (24.69\%) and peel (21.83\%) (Table 1). Boerboom (1978) and Islam et al. (2008) also observed similar results in fewer accessions. Howeler and Cadavid (1983), however, observed higher DM of tuber $(50-60 \%)$. This difference could be due to variation in genotype and locations between the experiments.

\section{Dry matter (DM) content of starch, pulp and flour}

Starch: The DM content of starch of cassava varied significantly $(P \leq 0.05)$ among the seven accessions and it was greater in Sa- $\mathrm{A}_{4}(88.11 \%)$ than in $\mathrm{Kh}-\mathrm{A}_{2}$ and $\mathrm{Me}-\mathrm{A}_{5}$ (average of $86.90 \%$ ), Cow- $\mathrm{A}_{3}(84.97 \%$ ), Coc- $A_{1}(83.12 \%)$ (Table 2). Pulp: The DM content of pulp varied significantly $(P \leq 0.05)$ among the seven cassava accessions and it was greater in Coc- $A_{1}$, Cow- $A_{3}$ and $K h-A_{2}$ (average of $90.76 \%$ ) than in Sa- $A_{4}$ and $\mathrm{Me}-\mathrm{A}_{5}$ (average of $\left.86.2 \%\right), \mathrm{Va}-\mathrm{A}_{6}(85.16 \%)$ and $\mathrm{Sy}-\mathrm{A}_{8}(81.72 \%)$ (Table 2). Flour: The DM of flour varied from $80.38 \%$ in $\mathrm{Va}-\mathrm{A}_{6}$ to $89.35 \% \mathrm{Kh}-\mathrm{A}_{2}$ (Table 2). It was greater in Kh- $\mathrm{A}_{2}$ (89.35\%) than in Coc- $\mathrm{A}_{1}$ (88.08\%), Cow- $\mathrm{A}_{3}$ and $\mathrm{Me}-\mathrm{A}_{5}$ (average of $85.88 \%$ ) and Sa- $\mathrm{A}_{4}(84.77 \%$ ) (Table 2).

Table 2. Dry matter content of tuber, starch, pulp and flour in seven cassava accessions

\begin{tabular}{|l|c|c|c|}
\hline \multirow{2}{*}{ Accessions } & \multicolumn{2}{|c|}{ Dry matter content (\%) } \\
\cline { 2 - 4 } & Starch & Pulp & Flour \\
\hline Coc- $_{1}$ & $83.12 \mathrm{~d}$ & $92.41 \mathrm{a}$ & $88.08 \mathrm{~b}$ \\
\hline $\mathrm{Kh}_{2} \mathrm{~A}_{2}$ & $86.73 \mathrm{~b}$ & $90.95 \mathrm{a}$ & $85.35 \mathrm{a}$ \\
\hline Cow-A & $80.93 \mathrm{a}$ & $\mathrm{c}$ \\
\hline Sa-A & $84.97 \mathrm{c}$ & $85.35 \mathrm{bc}$ & $85.77 \mathrm{~d}$ \\
\hline $\mathrm{Me}_{4} \mathrm{~A}_{5}$ & $88.11 \mathrm{a}$ & $87.05 \mathrm{~b}$ & $\mathrm{c}$ \\
\hline Va- $\mathrm{A}_{6}$ & $87.08 \mathrm{ab}$ & $85.16 \mathrm{c}$ & $80.38 \mathrm{e}$ \\
\hline Sy-A & $82.35 \mathrm{de}$ & $81.72 \mathrm{~d}$ & $80.48 \mathrm{e}$ \\
\hline Mean & $81.92 \mathrm{e}$ & 87.65 & 84.98 \\
\hline
\end{tabular}

In a column, numbers followed by different letters differ significantly at $P \leq 0.05$ by DMRT

Preparation of cassava products such as flour, pulp, starch, chips, pellets etc. depends on DM content. Therefore, DM determination of starch, pulp and flour is important. Generally, $10-12 \%$ moisture i.e. 88$90 \%$ DM is good for flour production (IITA, 2005). However, in the current research flour moisture content varied from $10-20 \%$. It could be due to improper drying in the sun. For short term storage flour must be dried within the stipulated range.

\section{Peeling ratio, starch and flour yield, and HCN content of tuber}

Peeling ratio: Weight of the peel to tuber i.e. peeling ratio of cassava tuber varied significantly $(P \leq 0.05)$ among the seven cassava accessions and it was greater in Coc- $A_{1}$ and Sa-A (average of 19.62\%) than in $\mathrm{Me}-\mathrm{A}_{5}(17.79 \%), \mathrm{Kh}-\mathrm{A}_{2}(16.42 \%)$, Sy- $\mathrm{A}_{8}(14.40 \%)$ and $\mathrm{Va}-\mathrm{A}_{6}(12.91 \%)$ (Table 3). Starch content: Tuber starch content varied from $15.04 \%$ in Sy- $\mathrm{A}_{8}$ to $25.05 \%$ in Coc- $\mathrm{A}_{1}$. It was significantly greater in Coc$\mathrm{A}_{1}$ and $\mathrm{Me}-\mathrm{A}_{5}$ (average of $24.97 \%$ ) than $\mathrm{Kh}-\mathrm{A}_{2}$ and Cow- $\mathrm{A}_{3}$ (average of $21.73 \%$ ), Sa- $\mathrm{A}_{4}$ and $\mathrm{Va}-\mathrm{A}_{6}$ (average of $17.19 \%$ ) and Sy- $\mathrm{A}_{8}(15.04 \%)$ (Table 3). Peel starch content: The Starch content of peel of cassava and it was greater in Coc- $\mathrm{A}_{1}(5.85 \%)$ than in Cow- $\mathrm{A}_{3}$, Sa- $\mathrm{A}_{4}$ and Me- $\mathrm{A}_{5}$ (average of $\left.5.32 \%\right)$, Kh$\mathrm{A}_{2}(5.19 \%), \mathrm{Sy}-\mathrm{A}_{8}(4.85 \%)$ and $\mathrm{Va}-\mathrm{A}_{6}(4.54 \%)$ (Table 3). Flour Yield: Flour content varied from 101.89 $\mathrm{g} / \mathrm{kg}$ (average of Kh-A , Cow $-\mathrm{A}_{3}$ and $\mathrm{Va}-\mathrm{A}_{6}$ ) to $201.86 \mathrm{~g} / \mathrm{kg}$ (in Sy- $\mathrm{A}_{8}$ ). It was significantly greater in Sy- $\mathrm{A}_{8}$ $\left(201.86 \mathrm{~g} / \mathrm{kg}\right.$ ) than Coc- $\mathrm{A}_{1}, \mathrm{Sa}-\mathrm{A}_{4}$ and $\mathrm{Me}-\mathrm{A}_{5}$ (average of $162.44 \mathrm{~g} / \mathrm{kg}$ ) and $\mathrm{Kh}-\mathrm{A}_{2}$, Cow $-\mathrm{A}_{3}$ and Va- $\mathrm{A}_{6}$ (average of $101.89 \mathrm{~g} / \mathrm{kg}$ ) (Table 3). 
Tuber HCN content: The HCN content of fresh tuber varied significantly $(P \leq 0.05)$ among the seven cassava accessions (Table 3). It was greater in Va- $A_{6}\left(546.0 \mathrm{mg} / \mathrm{kg}\right.$ fresh weight) than in Sa- $\mathrm{A}_{4}(324.0$ $\mathrm{mg} / \mathrm{kg}$ fresh weight), Cow- $\mathrm{A}_{3}$ (244.4 mg/kg fresh weight), $\mathrm{Kh}-\mathrm{A}_{2}$ and Me- $\mathrm{A}_{5}$ (average of $215.6 \mathrm{mg} / \mathrm{kg}$ fresh weight) and $S y-A_{8}$ and Coc- $A_{1}$ (average of $140.95 \mathrm{mg} / \mathrm{kg}$ fresh weight) (Table 3).

Table 3. Peeling ratio, starch and flour yield, and hydrogen cyanide (HCN) contents (fresh wt. basis) in seven cassava accessions

\begin{tabular}{|c|c|c|c|c|c|}
\hline \multirow{2}{*}{ Accessions } & \multirow{2}{*}{$\begin{array}{c}\text { Peeling ratio (peel } \\
\text { to tuber) }\end{array}$} & \multicolumn{2}{|c|}{ Starch \% (fresh wt.) } & \multirow{2}{*}{$\begin{array}{c}\text { Flour yield } \\
(\mathrm{g} / \mathrm{kg})\end{array}$} & \multirow{2}{*}{$\begin{array}{c}\text { Tuber HCN } \\
(\mathrm{mg} / \mathrm{kg})\end{array}$} \\
\hline & & Tuber & Peel & & \\
\hline Coc- $A_{1}$ & $19.89 \mathrm{a}$ & $25.05 a$ & $5.85 \mathrm{a}$ & $162.03 \mathrm{~b}(16.20)^{+}$ & $137.20 \mathrm{e}$ \\
\hline Kh-A $A_{2}$ & $16.42 \mathrm{c}$ & $21.56 \mathrm{~b}$ & $5.19 \mathrm{c}$ & $107.59 \mathrm{c}(10.76)$ & $217.01 \mathrm{~d}$ \\
\hline Cow- $A_{3}$ & $17.35 \mathrm{bc}$ & $21.91 \mathrm{~b}$ & $5.30 \mathrm{~b}$ & 098.14 c (09.81) & $244.42 \mathrm{c}$ \\
\hline $\mathrm{Sa}-\mathrm{A}_{4}$ & $19.35 \mathrm{a}$ & $17.61 \mathrm{c}$ & $5.27 \mathrm{~b}$ & $166.35 \mathrm{~b}(16.63)$ & $324.06 \mathrm{~b}$ \\
\hline $\mathrm{Me}-\mathrm{A}_{5}$ & $17.79 \mathrm{~b}$ & $24.90 \mathrm{a}$ & $5.54 \mathrm{~b}$ & $158.94 \mathrm{~b}(15.89)$ & $214.28 d$ \\
\hline Va-A $A_{6}$ & $12.91 \mathrm{e}$ & $16.78 \mathrm{c}$ & $4.54 \mathrm{e}$ & $99.94 \mathrm{c} \quad(09.99)$ & $546.01 \mathrm{a}$ \\
\hline Sy-A $A_{8}$ & $14.40 \mathrm{~d}$ & $15.04 \mathrm{~d}$ & $4.85 \mathrm{~d}$ & 201.86 a (20.18) & $144.70 \mathrm{e}$ \\
\hline Mean & 16.87 & 20.41 & 5.22 & $142.12 \quad(14.20)$ & 261.04 \\
\hline
\end{tabular}

In a column, numbers followed by different letters differ significantly at $\mathrm{P} \leq 0.05$ by DMRT, +: Figures within parenthesis indicate percentage flour yield

Genetic variation for tuber mean starch content (15.04-25.05\%) was observed in the current study (Table 3). This supports the results of Sajeev et al. (2003) who also observed variations in starch (20-25 $\%$ ) in fresh tuber. Of the $100 \mathrm{~g}$ fresh tuber, there were $20.41 \mathrm{~g}$ starch, $14.20 \mathrm{~g}$ flour and the rest, $65.39 \mathrm{~g}$ water on mean weight basis (Table 3). On fresh weight basis, current cassava starch yield was greater (7.25 t/ha, mean of seven accessions, data not shown) than potato and sweet potato (6 t/ha), rice (3.2 $\mathrm{t} / \mathrm{ha}$ ), corn (2.5 t/ha) and wheat (2.4 t/ha) (Jannat, 2011). Variation also existed for HCN content in tuber. Lethal dose of $\mathrm{HCN}$ is $50 \mathrm{mg} / \mathrm{kg}$ fresh weight. But $\mathrm{HCN}$ could almost be removed by proper processing. $\mathrm{HCN}$ produced during harvesting, chopping, boiling, drying, blending and other postharvest operations are almost removed (Bokanga et al., 1994; Fakir et al., 2009, 2010). The flour and starch thus produced was free of toxicity since HCN was not detected there.

\section{Tuber proximate composition}

Crude protein: The crude protein was greater in Va- $\mathrm{A}_{6}(4.53 \%)$ than in Coc- $\mathrm{A}_{1}$ and Sa- $\mathrm{A}_{4}$ (average of $2.92 \%$ ), Kh- $A_{2}$, Cow $-A_{3}$ and $S y-A_{8}$ (average of 1.80\%) (Table 4). Crude fiber: Crude fiber content significantly varied from $1.95 \%$ in Coc- $\mathrm{A}_{1}$ and Sa- $\mathrm{A}_{4}$ to $4.27 \%$ in Cow- $\mathrm{A}_{3}$ (Table 4). It was significantly greater in Cow- $\mathrm{A}_{3}(4.27 \%)$ than Coc- $\mathrm{A}_{1}$ and Sa-A $\mathrm{A}_{4}$ (average of $\left.1.95 \%\right)$. Crude fat (Etheral extract, EE): EE content of cassava varied significantly $(P \leq 0.05)$ and it was greater in Va- $A_{6}(1.87 \%)$ than Sa- $A_{4}$ $(0.80 \%)$ (Table 4$)$. Ash: The ash or mineral content of cassava varied significantly $(P \leq 0.05)$ among the seven accessions and it was greater in $M e-A_{5}$ and $V a-A_{6}$ (average of $5.53 \%$ ) than Cow- $A_{3}$ and Kh- $A_{2}$ (average of $3.65 \%$ ) (Table 4). Total Carbohydrate (Nitrogen free extract, NFE): The NFE content of cassava tuber varied significantly $(P \leq 0.05)$ among the seven accessions (Table 4). It was greater in Kh$\mathrm{A}_{2}(91.10 \%)$ than in Me- $\mathrm{A}_{5}(87.92 \%)$ and Va-A $\mathrm{A}_{6}(84.35 \%)($ Table 4$)$.

Cassava tuber is used as staple food, feed and vegetables (Grace, 1977; Charles et al., 2005; Fakir et al., 2010). Proximate composition such as crude protein, crude fiber, crude fat, ash and NFE of tuber is important. (Hang et al., 2007). Genetic variation for proximate composition in seven accessions was observed and therefore, selection for genotype with good nutrients is possible. High protein $(4.53 \%)$ in Va- $A_{6}$ may not be useful since it also contained high $\mathrm{HCN}(546 \mathrm{mg} / \mathrm{kg}$ fresh wt.). However, nature and duration of processing like chopping, threshing, boiling etc. reduces as much as $95 \% \mathrm{HCN}$ (Montagnac et al., 2009; Fakir et al., 2009, 2010). Therefore, processing is important in this case. Genetic variations for DM content of plant parts; and flour, starch and HCN content of tuber existed. There is, therefore, opportunity for selection of improved genotype(s) for higher DM, flour and starch yield. Further, selected genotypes could be used as parent(s) to develop high yielding varieties. It appears that the Coc- $A_{1}$ would be a better accession based on DM and nutrients contents. 
Table 4. Proximate composition of tuber of seven cassava accessions

\begin{tabular}{|l|c|c|c|c|c|}
\hline \multirow{2}{*}{ Accessions } & \multicolumn{5}{|c|}{ Proximate composition of tuber (\%) } \\
\cline { 2 - 6 } & Crude protein & Crude fiber & Crude fat & Ash & NFE $^{\dagger}$ \\
\hline Coc- $_{1}$ & $2.83 b$ & $1.66 \mathrm{c}$ & $1.52 \mathrm{ab}$ & $4.55 \mathrm{ab}$ & $89.42 \mathrm{bc}$ \\
\hline $\mathrm{Kh}_{2} \mathrm{~A}_{2}$ & $1.92 \mathrm{c}$ & $2.45 \mathrm{bc}$ & $1.18 \mathrm{abc}$ & $3.84 \mathrm{~b}$ & $91.18 \mathrm{a}$ \\
\hline Cow-A & $1.68 \mathrm{c}$ & $4.27 \mathrm{a}$ & $1.44 \mathrm{abc}$ & $3.47 \mathrm{~b}$ & $89.12 \mathrm{bc}$ \\
\hline Sa- $\mathrm{A}_{4}$ & $3.01 \mathrm{~b}$ & $2.24 \mathrm{c}$ & $0.80 \mathrm{~d}$ & $4.04 \mathrm{ab}$ & $89.90 \mathrm{ab}$ \\
\hline $\mathrm{Me}-\mathrm{A}_{5}$ & $2.56 \mathrm{bc}$ & $2.88 \mathrm{bc}$ & $1.33 \mathrm{abcd}$ & $5.47 \mathrm{a}$ & $87.92 \mathrm{c}$ \\
\hline $\mathrm{Va}-\mathrm{A}_{6}$ & $4.53 \mathrm{a}$ & $3.60 \mathrm{ab}$ & $1.87 \mathrm{a}$ & $5.60 \mathrm{a}$ & $84.35 \mathrm{~d}$ \\
\hline Sy-A & $1.81 \mathrm{c}$ & $2.65 \mathrm{bc}$ & $0.86 \mathrm{~cd}$ & $4.41 \mathrm{ab}$ & $90.26 \mathrm{ab}$ \\
\hline Mean & 2.62 & 2.82 & 1.29 & 4.48 & 88.88 \\
\hline
\end{tabular}

In a column, numbers followed by different letters differ significantly at $\mathrm{P} \leq 0.05$ by $\mathrm{DMRT},{ }^{\dagger}$ : Nitrogen free extract

\section{References}

Alves, A.A.C. 2002. Cassava biology and physiology, In: Cassava biology, production and utilisation. eds. Hillocks, R.J., Thresh, J.M., Beltotti, A.C., p. 67-90, CAB Intl. Oxford

Anonymous, H. 2004. Hydrogen cyanide and cyanides: human health aspects, Concise Int. Chem. Assessment Doc. 61, World Health Org.

AOAC (Association of Official Agricultural Chemists) 1990. $15^{\text {th }}$ ed. Association of official analytical chemistry, Washington DC.

Benesi, I.R.M., Labuschagne, M.T., Dixon, A.G.O. and Mahungu, N.M. 2004. Stability of native starch quality parameters, starch extraction and root dry matter of cassava genotypes in different environments, J. Sci. Food Agric., 84: 1381-1388.

Boerboom, B.W.J. 1978. A model of dry matter distribution in cassava (Manihot esculenta Crantz). Netherlands J. Agric. Sci., 26: 267-277.

Bokanga, M., Ekanayake, I.J., Dixon, A.G.O. and Proto, M.C.M. 1994. Genotype-environment interaction for cyanogenic potential in cassava. Acta. Hort., 375:131-139.

Charles, A.L., Sriroth, K. and Tozou-chi, H. 2005. Proximate composition, mineral contents, hydrogen cyanide and phytic acid of 5 cassava genotypes. Food Chem., 92(4): 615-620.

Fakir, M.S.A., Mostafa, M.G. and Seal, H.P. 2009. Food security in Bangladesh: Evaluation of cassava (Manihot esculenta) morphotypes based on hydrogen cyanide acid toxicity and protein content of tuber. Poster presented In Natl. Symp. Climate change, plant protection \& food security interface, Assoc. Advan. Plant protection, BCKV, Kalyani, India, 17-19 Dec., 2009, p. 59

Fakir, M.S.A., Mostafa, M.G. and Seal, H.P. 2010. Food security in Bangladesh: Selection, nutritional status evaluation of processing technique of cassava strains for use as a potential human and animal food. Poster presented In Intl. Conf. "Food security during challenging times" Univ. Putra Malaysia, Selangor, Malaysia, 5-7 July, 2010. p. 218-220.

Fakir, M.S.A., Talukder, M.H.R., Mostafa, M.G. and Rahman, M.S. 2011. Debranching effect on growth and yield in cassava. J. Agrofor. Environ., 5(1): 1-5.

Fakir, M.S.A., Mostafa, M.G., Jannat, M., Islam, F. and Seal, H.P. 2012. Dry mass content of plant parts, flour extraction and nutrient contents of tuber of cassava accessions. Abst. In. Souvenir, 3rd Intl. Seed Conf., 'Quality seed and food security under changing climate', Seed Sci Soc. Bangladesh, Bangladesh Agric. Univ., Mymensingh, Bangladesh, 8-10 Feb, 2012. p. 41.

Gomez, K.A. and Gomez, A.A. 1984. Statistical procedure for agricultural research. $2^{\text {nd }}$ ed. John Wiley and Sons, New York. p. 680.

Grace, M.R. 1977. Cassava processing. Plant production and protection series, No. 3. FAO, Rome.

Hang, P., Preston, K.A. and Nassar, J.H. 2007. Proximate composition, hydrogen cyanide of two cassava genotypes. Phyto Chem., 56 (5): 215-217.

Hillocks, R.J. 2002. Origin, distribution and economic importance: Cassava in Africa. In: Cassava biology, production and utilisation. eds. Hillocks, R.J., Thresh, J.M., Beltotti, A.C., CAB Intl. Oxford, p. 40-45,

Howeler, R.H. and Cadavid, L. F. 1983. Accumulation and distribution of dry matter and nutrients during a 12 month growth cycle of cassava. Field Crops Res., 7: 123-139.

IITA (International Institute of Tropical Agriculture), 2011. Research highlights, P.M.B. 5320, Oyo state, Ibadan, Nigeria. p. 12.

Islam, A., Islam, A.T.M.T., Mostafa, M.G. and Fakir, M.S.A. 2008. Effect of branch number on growth and yield in two cassava morphotypes. Bangladesh J. Agric., 1(1): 1-6.

Jannat, M. 2011. Dry mass content of plant parts, flour extraction and nutrient contents of tuber of cassava (Manihot esculenta) accessions, MS Thesis, Dep. Crop Botany, Bangladesh Agric. Univ. Mymensingh.

Montagnac, J.A., Christopher, R.D. and Tanumi, S.A. 2009. Processing technique to reduce toxicity and antinutrients of cassava for use as staple food. Comprehensive Rev. Food Sci. Food Safety, 8:17-27.

Purseglove, J.W. 1988. Tropical Crops dicotyledons, ELBS, Longman, U.K.

Sajeev, M.S., Moorthy, S.N., Kailappan, R. and Rani, V.S. 2003. Gelatinisation characteristics of cassava starch settled in the presence of different chemicals. Starch., 55: 213-221.

Siritunga, D., Garzon, D.A., White, W. and Seyre, R.T. 2004. Over-expression of hydroxynitrile lyase in transgenic cassava root accelerates cyanogenesis and food detoxification. J. Plant Botechnol., 2: 37-43. 